\title{
Pendapatan Pengelolaan Operasi Asuransi (Dana Ujrah) Dan Pengarunya Terhadap Laba/Rugi Pada PT. Asuransi Takaful Umum Di Indonesia
}

\author{
Oleh: \\ Muklis \\ Ria Haryani
}
Sekolah Tinggi Ekonomi Syariah (STES) Islamic Village Tangerang Jl. Islamic Raya Kelapa Dua Tangerang-Banten

\begin{abstract}
Abstrak: Penelitian ini bertujuan untuk mengetahui seberapa besar pengaruh pendapatan pengelolaan operasi asuransi (dana ujrah) terhadap Laba/Rugi pada PT. Asuransi Takaful Umum di Indonesia. Metode yang digunakan dalam penelitian ini menggunakan deskriptif kuantitatif, data yang digunakan dalam penelitian ini adalah data sekunder. Data sekunder diperoleh dari data Laporan Keuangan PT. Asuransi Takaful Umum publikan selama 5 (lima) tahun periode 2011 sampai dengan tahun 2015. Hasil penelitian menunjukan bahwa variabel Pendapatan Pengelolaan Operasi Asuransi (Dana Ujrah) (X1) berpengaruh signifikan terhadap variabel Laba/Rugi (Y) sebesar 0,048 sesuai dengan angka signifikan 0,048<0,005. Artinya, kenaikan pendapatan pengelolaan operasi asuransi (dana ujrah) akan mempengaruhi laba/rugi perusahaan.
\end{abstract}

Kata Kunci: Pendapatan Pengelolaan Operasi Asuransi (Dana Ujrah) dan Laba/Rugi PT. Asuransi Takaful Umum.

\section{Pendahuluan}

Kata "asuransi" diambil dari bahasa Belanda, "assurantie". Dalam hukum Belanda disebut "Verzekering", yang berarti pertanggungan. Istilah tersebut kemudian berkembang menjadi "assuradeur" yang berarti penanggung dan tertanggung disebut "geassureerde". Dalam Undang-Undang Republik Indonesia Nomor 2 Tahun 1992, pengertian asuransi adalah perjanjian antara dua pihak atau lebih; pihak penanggung mengikatkan diri kepada tertanggung, dengan menerima kontribusi bruto atau premi asuransi, untuk memberikan penggantian kepada tertanggung karena kerugian, kerusakan, atau kehilangan keuntungan yang diharapkan; atau tanggung jawab hukum kepada pihak ketiga yang mungkin akan diderita tertanggung, yang timbul dari suatu peristiwa yang tidak pasti; atau untuk memberikan suatu pembayaran 
yang didasarkan atas meninggal atau hidupnya seseorang yang dipertanggungkan.

Dari penjelasan di atas bahwa ruang lingkup usaha asuransi meliputi usaha jasa keuangan dengan cara menghimpun dana masyarakat melalui pengumpulan kontribusi bruto atau premi asuransi. Asuransi juga memberikan perlindungan kepada anggota masyarakat pemakai jasa asuransi terhadap kemungkinan timbulnya kerugian karena suatu peristiwa yang tidak pasti atau terhadap hidup atau meninggalnya seseorang.

Berdasarkan hasil survei penelitian dari laporan keuangan PT Asuransi Takaful Umum bahwa pengelola atau perusahaan asuransi syariah hanya bertugas sebagai wakil yang 'ditunjuk' oleh peserta atau nasabah bahwa dana kontribusi bruto atau premi yang dikumpulkan dari dana para peserta adalah hakekatnya milik peserta sebagai sebuah kumpulan. Istilah dana "tabarru" diperkenankan untuk memberikan gambaran bahwa dari $100 \%$ kontribusi bruto atau premi yang masuk tidak otomatis menjadi milik perusahaan asuransi seperti yang terjadi dalam Asuransi Konvensional. Dana tersebut harus dipecah atau dibagi menjadi 2 (dua) kategori: (1) dana tabarru, dan (2) dana ujrah. Dana tabarru adalah kontribusi bruto atau premi milik peserta secara keseluruhan yang diperuntukkan bagi pembayaran klaim kepada peserta yang mengalami musibah, sedangkan untuk pengeluaran perusahaan seperti pembayaran intensif agen, gaji karyawan, dan lain-lain diambil dari dana ujrah. Sehingga "ujrah" tidak semata-mata berkonotasi "komisi" namun lebih dari itu, biaya-biaya operasional perusahaan lainnya menjadi bagian dalam komponen ujrah ini.

\section{Landasan Teori}

Dalam bahasa Arab Asuransi disebut at-ta'min, penanggung disebut mu'ammin, sedangkan tertanggung disebut mu'amman atau musta'min. At- ta'min diambil dari kata aman memiliki arti memberi perlindungan, ketenangan, rasa aman, dan bebas dari rasa takut, sebagaimana firman Allah, "Dialah Allah yang mengamankan mereka dari ketakutan." (Quraisy: 4).

Menurut Mushtafa Ahmad Zarqa, makna asuransi secara istilah adalah kejadian. Adapun metodologi dan gambarannya dapat berbedabeda, namun pada intinya, asuransi adalah cara atau metode untuk memelihara manusia dalam menghindari risiko (ancaman) bahaya yang beragam yang akan terjadi dalam hidupnya, dalam perjalanan kegiatan hidupnya atau dalam aktivitas ekonominya. 
Laba ialah selisih positif antara pendapatan dikurangi beban (expenses), yang merupakan dasar ukuran kinerja bagi kemampuan manajemen dalam mengoperasikan harta perusahaan. Laba harus direncanakan dengan baik agar manajemen dapat mencapainya secara efektif. Sebelum dibuat perencanaan laba terlebih dahulu dibuat peramalan penjualan dan peramalah harga, dan diadakan klasifikasi biaya semi variabel. Tujuan klasifikasi biaya semi variabel adalah untuk menetapkan perilaku biaya ke dalam biaya tetap dan biaya variabel, selanjutya untuk memudahkan perencanaan laba.

PSAK 108 Akuntansi Transaksi Asuransi Syariah. Prinsip dasar dalam asuransi syariah adalah tolong menolong (ta'awun) dan saling menanggung (takafuli) antara sesama peserta asuransi. Akad yang digunakan dalam asuransi syariah adalah akad tabarru' dan akad tijari. Akad tabarru' digunakan diantara para peserta, sedangkan akad tijari digunakan antara peserta dengan entitas pengelola.

Dana tabarru' dibentuk dari donasi, hasil investasi, dan akumulasi cadangan surplus underwriting dana tabarru' yang didistribusikan kembali ke dana tabarru'. Hasil investasi dana tabarru' seluruhnya menjadi penambah dana tabarru', atau sebagian menjadi penambah dana tabarru' dan sebagian lainnya untuk entitas pengelola sesuai dengan akad yang disepakati. Pembayaran manfaat asuransi/klaim berasal dari dana peserta kolektif (dana tabarru') dimana risiko ditanggung secara bersama antara peserta asuransi.

Pengertian Ujrah. Ujrah adalah fee atau upah yang diberikan kepada entitas asuransi umum syariah atas jasa entitas asuransi umum syariah dalam mengelola dana tabarru' peserta. Ujrah dilandasi dengan akad wakalah bil ujrah. Ujrah akan menjadi milik perusahaan, yang dapat digunakan untuk biaya operasional perusahaan. Secara otomatis ujrah menjadi asset dana pemegang saham (DPS). Perusahaan tidak boleh menggunakan dana peserta tabarru' (DPT) untuk kebutuhan perusahaan. Perusahaan hanya berhak menggunakan ujrah untuk kebutuhan operasionalnya. 


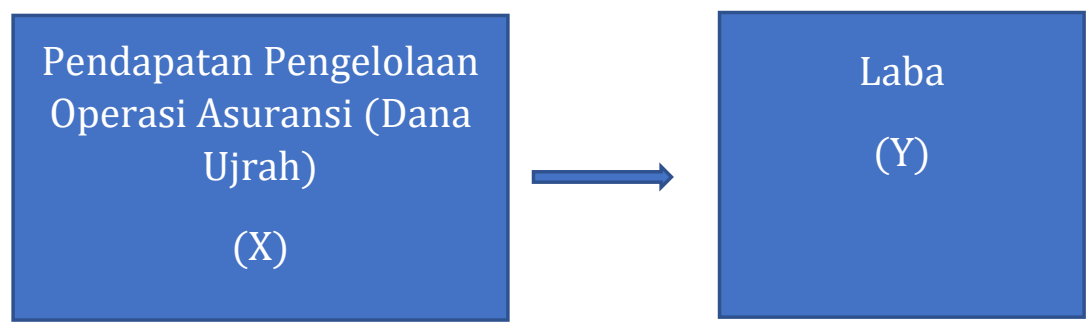

Gambar 2.1. Kerangka Pemikiran

Berdasarkan skema kerangka pemikiran, maka dapat dijelaskan sebagai berikut:

Premi merupakan sejumlah uang yang dilakukan pihak tertanggung kepada penanggung untuk mengganti suatu kerugian, kerusakan atau kehilangan keuntungan yang diharapkan akibat timbulnya perjanjian atas pemindahan risiko dari tertanggung kepada penanggung. Pendapatan premi merupakan salah satu faktor penambah dana tabarru' dan dana ujrah. Pada asuransi syariah, dana premi dibagi menjadi 2 (dua) kategori: (1) dana tabarru, dan (2) dana ujrah. Jika semakin banyak polis asuransi yang terjual kepada nasabah maka pendapatan pengelolaan operasi asuransi (dana ujrah) yang akan diperoleh perusahaan asuransi akan semakin meningkat.

Hipotesis Penelitian. Hipotesis merupakan jawaban sementara terhadap tujuan penelitian yang diturunkan dari kerangka pemikiran yang telah dibuat. Hipotesis merupakan pernyataan tentative tentang hubungan antara beberapa dua variabel atau lebih. Hipotesis ini dapat berupa pengaruh positif maupun negatif, tergantung variabel yang diuji. Dalam penelitian ini penulis mengangkat hipotesis sebagai berikut:

$\mathrm{H}_{0}$ : Pendapatan Pengelolaan Operasi Asuransi (Dana Ujrah) tidak berpengaruh terhadap Laba/Rugi pada Perusahaan Asuransi Takaful Umum di Indonesia Tahun 2011 sampai dengan tahun 2015.

Ha: Pendapatan Pengelolaan Operasi Asuransi (Dana Ujrah) berpengaruh positif terhadap Laba/Rugi pada Perusahaan Asuransi Takaful Umum di Indonesia Tahun 2011 sampai dengan tahun 2015. 


\section{Hasil Penelitian Dan Pembahasan}

Analisis Data

Dalam penelitian ini obyek yang diteliti merupakan PT. Asuransi Takaful Umum di Indonesia yang terdaftar pada Otoritas Jasa Keuangan (OJK) periode tahun 2011 - 2015. Serta laporan keuangan PT. Asuransi Takaful Umum yang telah diaudit dan dipublikasikan pada tahun 2011 2015.

Adapun yang menjadi pertimbangan dalam menentukan sampel adalah sebagai berikut:

1. PT. Asuransi Takaful Umum yang terdaftar di Otoritas Jasa Keuangan (OJK).

2. PT. Asuransi Takaful Umum yang dijadikan sampel dari laporan keuangan pada periode tahun 2011 - 2015 yang telah diaudit dan dipublikasikan.

Analisis statistik

Analisis statistik deskriptif memberikan suatu gambaran atau deskriptif suatu data yang dilihat dari rata-rata dan data standar deviasi dari masing- masing variabel penelitian. Hasil statistik deskriptif selengkapnya dapat dilihat dalam tabel:

Tabel 1

Statistik Deskriptif Variabel Pendapatan Pengelolaan Operasi Asuransi (Dana Ujrah) (X) dan Laba/Rugi (Y)

Descriptive Statistics

\begin{tabular}{|l|l|l|l|}
\hline & Mean & Std. Deviation & N \\
\hline Laba/Rugi & 2276,60 & 3064,533 & 5 \\
Pendapatan Pengelolaan Operas i & 61837,60 & 9539,455 & 5 \\
\hline
\end{tabular}

Sumber: data diolah dengan SPSS 21

Berdasarkan tabel 1hasil olah data statistik dengan mengunakan SPSS 21 menunjukan bahwa dilihat dari 5 sampel penelitian maka nilai rata-rata variabel Laba/Rugi (Y) tahun 2011 - 2015 sebesar 2276,60, dengan standar deviasi sebesar 3064,533, nilai rata-rata variabel Pendapatan Pengelolaan Operasi Asuransi (Dana Ujrah) tahun 2011 - 2015 sebesar 61837,60, dengan standar deviasi sebesar 9539,455. 
Pengujian Asumsi Klasik

Untuk memperoleh hasil regresi yang tidak bias, maka sebaiknya dilakukan uji asumsi klasik. Pengujian terhadap asumsi-asumsi regresi linier bertujuan untuk menghindari munculnya bias dalam analisis data serta untuk menghindari kesalahan spesifikasi model regresi yang digunakan. Pengujian Asumsi Klasik meliputi:

\section{Uji Normalitas}

Uji Normalitas terhadap asumsi klasik normalitas bertujuan untuk mengetahui apakah residual data dari model regresi linier memiliki distribusi normal atau tidak.

Ada dua cara untuk mendeteksi apakah residual berdistribusi normal atau tidak. Yaitu dengan uji grafik Normal Probability Plot dan uji statistik One- Sampel Kolmogorov - Smirnov Test. Apabila pada grafik normal probability plot tampak bahwa titik-titik menyebar berhimpit disekitar garis diagonal dan searah mengikuti garis diagonal, maka hal ini dapat disimpulkan bahwa residual data memiliki distribusi normal.

\section{Analisis Regresi Sederhana}

Setelah melakukan Uji Asumsi Klasik maka selanjutnya melakukan Uji Analisis Regresi Sederhana. Analisis regresi sederhana merupakan teknik analisis regresi yang menganalisis model secara sederhana dengan hanya menggunakan satu variabel independen dan satu variabel dependen. Model persamaannya sebagai berikut:

$\mathrm{Y}=\alpha+\beta \mathrm{X}$

Keterangan:

$\mathrm{Y}=$ Variabel laba

$\alpha=$ Konstanta

$\beta=$ Koefisien Variabel Independen

$\mathrm{X}=$ Variabel Pendapatan Pengelolaan Operasi Asuransi (Dana Ujrah)

Tabel 2

Hasil Uji Analisis Regresi Sederhana

Coefficientsa

\begin{tabular}{|l|l|l|l|l|}
\hline Model & Uns tandardized & Standardized & $t$ & Sig. \\
& Coefficients & Coefficients & & \\
& B & Std. Error & Beta & \\
\hline
\end{tabular}




\begin{tabular}{|l|l|l|l|l|l|}
\hline (Cons tant) & $-15233,027$ & 5468,576 & & $-2,786$ &, 069 \\
$\begin{array}{l}1 \text { Pendapatan Pengelolaan } \\
\text { Operas i Asurans i (Dana Ujrah) }\end{array}$ &, 283 &, 088 &, 881 & 3,232 &, 048 \\
& & & & & \\
\hline
\end{tabular}

a. Dependent Variable: Laba/Rugi

Sumber: data diolah dengan SPSS 21

Dari tabel 2 dapat diperoleh persamaan atau model regresi sebagai berikut: $\mathrm{Y}=-15233,027+0,283 \mathrm{X}$ Ketika tidak ada tambahan dari Pendapatan Pengelolaan Operasi Asuransi (Dana Ujrah) maka Laba/Rugi sebesar -15233,027 satuan, dan apabila adanya tambahan dari Pendapatan Pengelolaan Operasi Asuransi (Dana Ujrah) sebesar satu satuan maka Laba/Rugi bertambah 0,283 satuan.

Pengujian Hipotesis

Pengujian hipotesis dalam penelitian ini dilakukan dengan melalui tahap pengujian model regresi secara parsial atau (uji t).

1. Pengujian secara parsial (uji t)

Uji t adalah uji hipotesis atau variabel independen yang dilakukan secara individu (parsial) terhadap variabel dependen. Pengujian secara parsial pada variabel X (Dana Ujrah) terhadap variabel Y (Laba/Rugi). Pengujian hipotesis ini dilakukan dengan menggunakan uji-t setelah nilai thit ung untuk koefisien regresi variabel Pendapatan Pengelolaan Operasi Asuransi (Dana Ujrah) (X) diketahui, kemudian dibandingkan dengan nilai tt abel dari tdist ribut ion untuk $\alpha=0,05$ pada pengujian dua sisi.

Hasil pengujian secara parsial variabel Pendapatan Pengelolaan Operasi Asuransi (Dana Ujrah) (X) terhadap Laba/Rugi (Y) dalam pengujian ini sebagai berikut.

Tabel 3

Uji Secara Parsial

Coefficientsa

\begin{tabular}{|l|l|l|l|l|}
\hline Model & $\begin{array}{l}\text { Uns tandardized } \\
\text { Coefficients }\end{array}$ & $\begin{array}{l}\text { Standardized } \\
\text { Coefficients }\end{array}$ \\
& $\mathrm{B}$ & Std. Error & Beta & Sig. \\
\hline
\end{tabular}




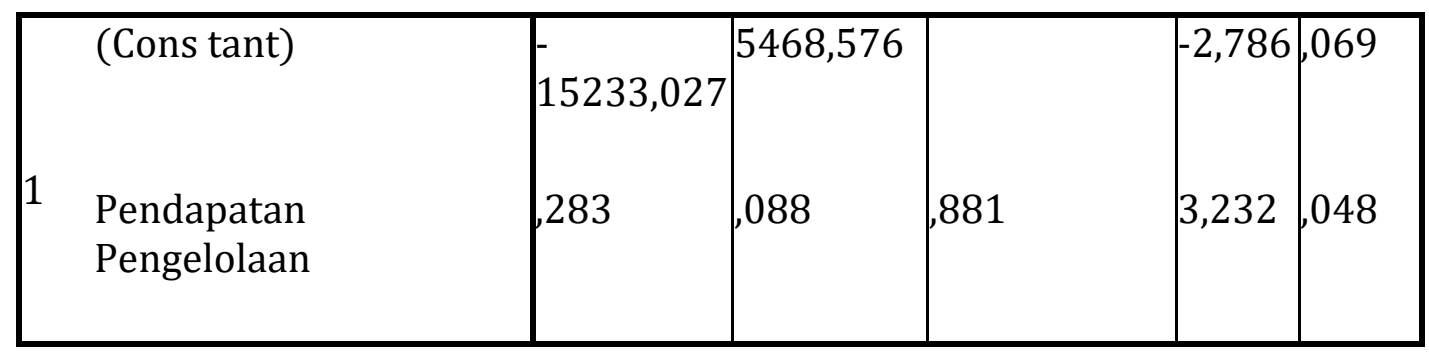

a. Dependent Variable: Laba/Rugi

Sumber: data diolah dengan SPSS 21

Berdasarkan pada hasil uji secara parsial diatas, ditunjukkan bahwa pengujian variabel Pendapatan Pengelolaan Operasi Asuransi (Dana Ujrah) (X) terhadap Laba/Rugi (Y) menghasilkan nilai thit ung sebesar 3,232 dengan tt abel 2,353 $(3,232<2,353)$ dan dengan tingkat signifikansi 0,048 . Oleh karena nilai signifikan $<\alpha=0,05$ maka dapat disimpulkan hasil ini sesuai dengan hipotesis , bahwa Ha diterima dan Ho ditolak. Yang artinya bahwa Pendapatan Pengelolaan Operasi Asuransi (Dana Ujrah) (X) berpengaruh signifikan terhadap Laba/Rugi (Y).

\section{Kesimpulan}

Berdasarkan hasil analisis data dan pembahasan pada bab sebelumnya. Maka dapat disimpulkan sebagai berikut: terdapat pengaruh dan signifikan antara variabel Pendapatan Pengelolaan Operasi Asuransi (Dana Ujrah) (X) terhadap Laba/Rugi (Y) sebesar 0,048 sesuai dengan angka signifikan 0,048 $<0,005$. Dengan kata lain variabel Dependen Laba/Rugi (Y) terhadap variabel Independen Pendapatan Pengelolaan Operasi Asuransi (Dana Ujrah) (X). Dimana nilai konstanta pada variabel dependen laba/rugi sebesar - 15233,027 satuan, dan apabila adanya tambahan dari Pendapatan Pengelolaan Operasi Asuransi (Dana Ujrah) sebesar satu satuan maka Laba/Rugi bertambah 0,283 satuan.

1. Dari hasil hipotesa diatas pada praktiknya Pendapatan Pengelolaan Operasi Asuransi (Dana Ujrah) sangat berpengaruh langsung pada Laba/Rugi perusahaan asuransi. Sehingga dapat disimpulkan bahwa:

a. Jika pendapatan pengelolaan operasi asuransi (dana ujrah) tetap atau tidak adanya kenaikan, sementara biaya operasional meningkat maka perusahaan asuransi cenderung merugi, dikarenakan biaya operasional lebih besar dibandingkan dengan pendapatan yang diperoleh oleh perusahaan.

b. Jika pendapatan pengelolaan operasi asuransi (dana ujrah) mengalami kenaikan, namun kenaikan yang didapat masih 
lebih besar dari kenaikan biaya operasional maka perusahaan asuransi cenderung mengalami kerugian.

c. Jika pendapatan pengelolaan operasi asuransi (dana ujrah) menurun sementara untuk biaya operasional tetap maka perusahaan asuransi cenderung mengalami kerugian.

\section{Daftar Pustaka}

Amrin, Abdullah. Asuransi Syariah. Jakarta: PT. Alex Media Komputindo. 2006. Amrin, Abdullah. Asuransi Syariah: Keberadaan dan Kelebihannya di Tengah Asuransi Konv ensional. Jakarta: PT. Alex Media Komputindo. 2006.

Fauziah, Nurul. Seberapa Besar Pengaruh Pembiayaan Musyarakah dan Pembiayaan Mudharabah Terhadap Laba Bersih pada Bank Umum Syariah. Program Studi Perbankan Syariah. 2014.

Fadlullah, Arief. Pengaruh Pendapatan Premi dan Hasil Investasi Terhadap Cadangan Dana Tabarru' (Studi pada PT. Asuransi Sinarmas Syariah). Fakultas Syariah dan Hukum Universitas Islam Negeri Jakarta. 2014.

Gunawan, Imam. PENGANTAR STATISTIKA INFERENSIAL. Depok: PT. Rajagrafindo Persada. 2016.

Hisamuddin, Nur. Implementasi Akuntansi Akad Wakalah Bil Ujrah Perusahaan Asuransi Syariah Berdasarkan PSAK 108: Studi di PT Asuransi Takaful Keluarga. 2014.

Khotimah, Husnul. Pengaruh Premi, Klaim, Hasil Investasi dan Underwriting Terhadap Laba Perusahaan Asuransi Syariah pada PT. Asuransi Kerugian Sinarmas Cabang Syariah Periode 2008 - 2012. Fakultas Syariah dan Hukum Universitas Islam Negeri Jakarta. 2014. Kuswadi. Meningkatkan Laba Melalui Pendekatan Akuntansi Keuangan dan Akuntansi Biaya. Jakarta: PT. Elex Media Komputindo, Kristianto. 2005.

Djoko. Implikasi Akuntansi Syariah dan Asuransi Syariah Dalam Lembaga Keuangan Syariah. Jurnal Akuntansi dan Sistem Teknologi Informasi. 2009.

Lathif, Azharuddin. Jurnal Al-Iqtishad. Fakultas Syariah dan Hukum Universitas Islam Negeri Jakarta. 2012.

Muhammad, Rifqi. Akuntansi Keuangan Syariah (Konsep dan Implementasi PSAK Syariah). Yogyakarta: P3EI Press. 2008.

Nasution, Mustafa Edwin. Pengenalan Eksklusif: Ekonomi Islam. Jakarta: Kencana Prenada Media Group. 2007. 
Novi, Model Proporsi Tabarru' dan Ujrah pada Bisnis Asuransi Umum Syariah di Indonesia. Jurnal Akuntansi dan Keuangan Indonesia. 2012.

Nugroho, Bhuono Agung. Strategi Jitu Memilih Metode Statistik Penelitian dengan SPSS. Yogyakarta: CV. Andi Offset. 2005.

Prawironegoro, Darsono. Akuntansi Manajemen. Jakarta: Diadit Media. 2005.

Puspitasari, Novi. Manajemen Asuransi Syariah. 2015.

Sugiyono. Metode Penelitian Kombinasi (Mixed Methods). Bandung: ALFABETA. 2015.

Sugiyono. Statistika untuk Penelitian. Bandung: ALFABETA. 2012.

Sujarweni, V. Wiratna. Metodologi Penelitian. Yogyakarta: PB Pustaka Baru Press. 2014.

Sula, Muhammad Syakir. Asuransi Syariah (Life and General). Jakarta: Gema Insani. 2004.

Sumanto, A.E., E. Priarto., M. Zamachsyari, P. Trihadi, R. Asmuji, R. Maulana.. Solusi Berasuransi: Lebih Indah dengan Syariah. Bandung: PT Karya Kita. 2009.

Supardi. Aplikasi Statistika dalam Penelitian Konsep Statistika yang Lebih Komprehensif. Jakarta: Change Publication. 2013.

Yunia, Mega. Pengaruh Pembiayaan Akad Murabahah Terhadap Laba Bank Syariah Yang Terdaftar Di Bursa Efek Indonesia. 2014.

www.jasaraharja-putera.co.id/tahun-ini-kontribusi-bruto-asuransisyariah-diprediksi-tumbuh-25-30/ www.takafulumum.co.id www.takafulmulia.com 